\title{
Internalisasi Nilai Disiplin melalui "Perencanaan" Orang Tua dalam Membentuk Karakter Baik Remaja
}

\author{
Antonius A. Saetban \\ Pendidikan Guru Sekolah Dasar, Universitas Tribuana Kalabahi-Alor \\ antonsaetban@gmail.com
}

\begin{abstract}
Abstrak
Internalisasi sebagai proses penanaman nilai kedalam jiwa seseorang sehingga nilai tersebut tercermin pada sikap dan prilaku yang ditampakan dalam kehidupan seharihari. Pandangan hidup, cara hidup, dan tujuan hidup orang tua akan berdampak bagi remaja. Orang tua dituntut untuk tidak hanya sekedar memberikan ceramah melalui kata-kata, tetapi perlu merencanakan nilai disiplin yang baik dengan cara memberikan contoh kongkrit kepada remaja. Karena itu, dilakukan penelitian kualitatif ini untuk melihat bentuk kedisiplinan dari masing-masing orang tua yang berbeda latar belakang dari pekerjaan dan status sosial. Data dalam penelitian ini diperoleh melalui wawancara tertulis dan observasi. Analisis data dilakukan secara deskriptif untuk mengidentifikasi perencanaan orang tua dalam menginternalisasi nilai disiplin. Hasil penelitian menunjukan bahwa tidak ada perbedaan yang cukup mendasar dalam hal perencanaan orang tua untuk menginternalisasikan nilai disiplin dalam menbentuk karakter baik remaja. Ketiga keluarga memberi perhatian serius sebagai wujud tanggung jawab orang tuadalam mendidik, mengawasi dan mengarahkan remaja.
\end{abstract}

Kata kunci: orang tua, perencanaan, internalisasi, nilai disiplin.

Dikirim: 8 Juli 2020

Direvisi: 13 Juli 2020

Diterima: 20 Juli 2020

\section{Identitas Artikel:}

Saetban, A. A. (2020). Internalisasi Nilai Disiplin melalui "Perencanaan" Orang Tua dalam Membentuk Karakter Baik Remaja. Jurnal Ilmu Pendidikan (JIP) STKIP Kusuma Negara, 12(1), 90-98.

\section{PENDAHULUAN}

Keluarga adalah wadah pertama dan utama bagi pertumbuhan dan pengembangan karakter remaja. Proses pembelajaran remaja untuk mengenal dan mengalami kehidupan baik secara individu ataupun sebagai warga masyarakat berlangsung pertama-tama melalui lingkungan keluarga. Jika suasana dalam keluarga itu baik dan menyenangkan, maka remaja akan tumbuh dengan baik pula. Jika tidak, maka pertumbuhan karakter baik remaja akan terhambat (Daradjat, 2003). Dalam membentuk karakter baik remaja, orang tua memiliki tanggung jawab untuk memberikan teladan yang baik bagi anak-anak yang telah dikaruniakan Tuhan kepada mereka. Segala hal yang berhubungan dengan pengetahuan, iman, dan pengalaman yang diterima oleh remaja salah satunya diperoleh dari orang tua sebagai sumber pendidikan yang utama dan pertama, artinya bahwa baik pengetahuan yang meliputi kecerdasan intelektual maupun karakter anak diperoleh dan dibentuk pertama-tama melalui keluarga. Dengan kata lain, bahwa keluarga dalam hal ini orang tua sebagai pribadi pertama dan utama berhak dan wajib membimbing, mengarahkan, dan mendidik kehidupan remaja (Gunarsa \& Gunarsa, 1988). 
Berkaitan dengan kehidupan remaja, pada umumnya remaja cenderung menirukan penampilan atau tingkah laku orang-orang tertentu yang dijadikan idola, seperti; orang tua, teman, guru, artis atau orang dewasa lainnya. Di lain sisi, remaja belum memiliki ketetapan karakter sehingga mudah diombang-ambingkan oleh situasi di sekitar. Dari berbagai situasi dan keadaan tersebut, remaja mulai mencoba mengikuti hal-hal yang dianggap menarik perhatian orang lain (Yusuf, 2004). Dengan adanya proses perkembangan demikian, maka orangtua sebagai sumber pendidikan yang pertama dan utama wajib menanamkan nilai-nilai karakter yang baik kepada remaja. Nilai-nilai karakter baik yang perlu ditanamkan pada remaja adalah nilai-nilai universal di mana seluruh agama, tradisi, dan budaya menjunjung tinggi nilai-nilai tersebut. Nilai-nilai universal ini harus dapat menjadi perekat bagi seluruh anggota masyarakat walaupun berbeda latar belakang budaya, suku, dan agama. Salah satu nilai universal yang perlu ditanamkan kepada remaja oleh orang tua adalah nilai disiplin. Nilai disiplin menjadi alat yang ampuh, karena kedisiplinan merupakan suatu latihan batin yang mencerminkan tingkah laku seseorang dalam berperilaku, dan nilai disiplin juga memiliki tujuan yang salah satunya adalah agar individu patuh pada peraturan.

Pandangan hidup, cara hidup, dan tujuan hidup orang tua akan berdampak bagi remaja itu sendiri, sehingga dalam proses internalisasi nilai disiplin, orang tua dituntut untuk tidak hanya sekedar memberikan ceramah melalui kata-kata tetapi lebih kepada memberikan contoh-contoh kongkrit melalui tindakan yang bertujuan untuk mewariskan nilai dan norma positif kepada remaja. Dalam proses menanamkan nilai disiplin, orang tua perlu merencanakan nilai-nilai yang baik sebagai teladan dengan cara memberikan contoh-contoh kongkrit kepada remaja. Contoh kongkrit yang dilakukan orang tua berupa ketaatan beribadah, tapat waktu, dan mengawasi aktivitas remaja. Contoh-contoh tersebut diharapkan dapat membentuk dan mengembangkan karakter disiplin remaja.

Proses internalisasi pada hakikatnya upaya menghadirkan sesuatu (nilai) yang asalnya ada pada dunia eksternal menjadi milik internal seseorang atau lembaga (Muhtar dkk., 2018). Oleh karena itu, dalam internalisasi nilai mengakui adanya nilai-nilai eksternal yang dipandang luhur, agung, penting (disepakati) yang harus diwariskan atau ditanamkan pada seseorang. Dengan kata lain internalisai dapat diartikan sebagai proses awal di mana individu mendapatkan norma, nilai, dan budaya dari lingkungan keluarga dan masyarakat sebagai bagian dari hasil belajarnya. Pernyataan yang sama bahwa internalisasi merupakan penanaman, pembentukan atau pemasukan seperangkat nilai ke dalam diri seseorang (Suryani, 2015; Nurizka \& Rahim, 2020), yang dilakukan oleh orang tua, pendidik, atau para ahli yang bertumpu pada tujuan, proses, dan hasil akhir. Pengertian ini bemberikan batasan bahwa internalisasi menghendaki adanya penanaman, apa yang ditanam, kepada siapa, di mana, kapan dan bagaimana cara menanamkannya. Objek kegiatan internalisasinya adalah personal, kemampuan yang ada padanya, potensi yang dimilikinya, dan bakat yang dibawanya.

Definisi ahli di atas, biasa dikatakan bahwa internalisasi sebagai proses penanaman nilai kedalam jiwa seseorang sehingga nilai tersebut tercermin pada sikap dan prilaku yang ditampakkan dalam kehidupan sehari-hari (menyatu dengan pribadi). Nilai-nilai yang di internalisasikan merupakan nilai yang sesuai dengan norma dan aturan-aturan yang berlaku di masyarakat. Proses internalisasi merupakan proses penghayatan yang berlangsung sepanjang hidup individu mulai 
saat dilahirkan hingga akhir hayatnya. Dengan demikian, orang tua perlu memberi perhatian ekstra kepada anak-anak khususnya remaja, sebab masa remaja adalah masa peralihan yang mana remaja akan berusaha untuk mencari pengakuan (Fatmawaty, 2017) bahkan sangat rentan terhadap hal-hal yang merusak dan membahayakan masa depannya.

\section{Perencanaan}

Perencanaan adalah penetapan pekerjaan yang harus dilaksanakan oleh kelompok untuk mencapai tujuan yang digariskan. Perencanaan mencakup kegiatan pengambilan keputusan. Untuk itu, diperlukan kemampuan untuk mengadakan visualisasi dan melihat kedepan guna merumuskan suatu pola tindakan untuk masa mendatang (Nadlir, 2013). Perencanaan dapat juga diartikan sebagai suatu cara untuk mengantisipasi dan mengeimbangkan perubahan. Definisi ini mengasumsikan bahwa perubahan selalu terjadi. Perubahan lingkungan harus selalu diantisipasi sehingga perubahan berimbang dengan perubahan dalam pendidikan keluarga (Uno, 2008).

Dengan demikian, perencanaan memiliki tiga makna. Pertama, perencanaan adalah usaha mencari wujud yang akan datang serta usaha untuk mencapainya; Kedua, perencanaan bermakna usaha menghilangkan kesenjangan antara keadaan masa sekarang dengan masa yang akan dating; Ketiga, perencanaan adalah usaha merubah keadaan agar sejalan dengan keadaan lingkungan yang juga berubah (Asroha, 2010).

\section{Disiplin}

Kedisiplinan adalah suatu kondisi yang tercipta dan terbentuk melalui proses dari serangkaian perilaku yang menunjukkan nilai-nilai ketaatan, kepatuhan, kesetiaan, keteraturan dan atau ketertiban. Karena sudah menyatu dengannya, maka sikap atau perbuatan yang dilakukan bukan lagi atau sama sekali tidak dirasakan sebagai beban, bahkan sebaliknya akan membebani dirinya bilamana ia tidak berbuat sebagaimana lazimnya (Prijodarminto, 1994). Tujuan kedisiplinan adalah perkembangan dari pengembangan diri sendiri dan pengarahan diri sendiri tanpa pengaruh atau kendali dari luar. Kedisiplinan adalah suatu latihan batin yang tercermin dalam tingkah laku yang bertujuan agar orang selalu patuh pada peraturan. Oleh karena itu, anak perlu dibimbing atau ditunjukkan mana perbuatan yang melanggar tata tertib dan mana perbuatan yang menunjang terlaksananya melalui sikap keteldanan yang baik.

Dari beberapa pendapat di atas, dapat disimpulkan bahwa tujuan kedisiplinan adalah memberi kenyamanan pada para anak dan orang tua serta menciptakan lingkungan rumah yang kondusif dalam kehidupan bersama serta perkembangan dari pengembangan diri sendiri dan pengarahan diri sendiri tanpa pengaruh atau kendali dari luar. Maka dapat dipahami bahwa disiplin adalah suatu sikap ketaatan secara sadar terhadap aturan, norma-norma, dan kaidah-kaidah yang berlaku agar terhindar dari hukuman dan dapat mencapai tujuan yang diharapkan.

\section{METODE PENELITIAN}

Metode yang digunakan adalah analisis deskriptif dengan pendekatan kualitatif. Penelitian ini bertujuan untuk melihat bentuk kedisiplinan dari masing-masing 
orang tua yang berbeda latar balakang, selanjutnya mendeskripsikan temuan data lapangan mengenai perencanaan internalisasi nilai disiplin orang tua dalam membentuk karakter baik remaja berupa tindakan, kondisi, dan kejadian yang berkaitan dengan tujuan penelitian. Sumber data diperoleh dari tiga keluarga yang berbeda latar belakang pekerjaan dan status sosial yaitu keluarga Pendeta, Pegawai Negeri Sipil (PNS) dan Buruh pelabuhan. Teknik pengumpulan data wawancara tertulis dan observasi. Wawancara dengan maksud untuk mendapatkan jawaban responden dan observasi melakukan pengamatan langsung aktivitas ketiga keluarga, bertujuan untuk memperkuat data hasil wawancara. Analisis data dilakukan secara deskriptif untuk mengidentifikasi internalisasi nilai disiplin orang tua dan manarik kesimpulan.

\section{HASIL DAN PEMBAHASAN}

Hasil penelitian ini diungkap melalui beberapa aktivitas orang tua dalam membentuk karakter baik remaja, yakni jadwal aktivitas, kataatan beribadah, ketepatan waktu, mengawasi anak di rumah dan di luar rumah, yang dapat dideskripsikan masing-masing pada bagian sebagai berikut:

\section{Jadwal Aktivitas}

Aktivitas Pendeta (Pimpinan Gereja/umat) memang tak mudah, sebab padatnya pelayanan membuat keluarga Pendeta kadang tak mudah untuk selalu bersama dengan anak-anak di rumah, tapi tetap tanggung jawab sebagai orang tua tidak bisa diabaikan, perlu mengatur waktu khusus untuk bersama dengan anak-anak. untuk berdiskusi tentang aktivitas anak di rumah termasuk memantau perkembangan studi anak. Demikian juga halnya dengan keluarga PNS dan Keluarga Buruh.

Hasil wawancara, Keluarga Pendeta: menjawab bahwa jadwal aktivitas di dalam rumah ada tapi tidak tertulis dengan alasan bahwa walaupun tidak tertulis tapi masing-masing sudah tahu bagiannya untuk dilakukan, sedangkan untuk jadwal di luar rumah berhubungan dengan aktivitas di kantor gereja dan untuk pelayanan/ ibadah rutin di jemaat. Keluarga PNS: menjawab di rumah maupun di luar rumah ada (misalnya: setiap malam ada doa bersama di rumah, sedangkan untuk di luar rumah jadwal mengajar dan jadwal ibadah wanita). Keluarga Buruh: menjawab bahwa jadwal di rumah tidak ada tapi di luar rumah ada (setiap hari harus absen kerja di kantor).

Berangkat dari hasil wawancara di atas, ketiga orang tua berupaya untuk mempersiapakan sekaligus membentuk anak lewat setiap aktivitas yang diterapkan di rumah dan di luar rumah. Hal ini, terlihat dari jawaban ketiga kategori orang tua, tidak ada perbedaan tapi sama-sama memiliki jadwal kerja di rumah dan di luar rumah, kecuali keluarga buruh yang tidak ada jadwal aktivitas di rumah. Jawaban ketiga keluarga di atas, didukung dari dari hasil observasi (Catatan Lapangan Peneliti) bahwa ketiga keluarga ini, sangat disiplin dalam bekerja baik di rumah maupun di luar rumah, hal ini dipengaruhi dengan padatnya agenda kerja dari masing-masing keluarga baik itu pendeta, PNS, dan buruh. Jadwal yang dibuat tidak hanya berlaku bagi orang tua, tapi dengan maksud masing-masing anggota keluarga dapat mentaatinya untuk dijalankan. Meskipun demikian, dalam prosesnya terkadang setiap agenda yang sudah diatur tidak 
berjalan karena berbagai faktor. Dengan adanya jadwal di rumah dan di luar rumah, secara tidak langsung orang tua menginternalisasikan unsur nilai disiplin melalui tindakan, di mana remaja sendiri belajar dan terbentuk untuk mengikuti model keteladanan yang ditampilkan dari masing-masing orang orang tua.

Hal di atas sejalan dengan kewajiban dan tanggung jawab sebagai orang tua untuk memberi teladan yang baik bagi anak. Fondasi dan dasar-dasar yang kuat adalah awal pendidikan dalam keluarga, dasar kokoh dalam menapaki kehidupan yang lebih berat, dan luas bagi perjalanan anak-anak manusia berikutnya (Jailani, 2014). Dengan demikian dapat dikatakan bahwa tiap-tiap keluarga mempunyai rencana kerja di luar rumah yang terjadwal sesuai dengan profesi kerja dari masing-masing keluarga.

\section{Ketaatan Beribadah}

Ketaatan beribadah yang dilakukan oleh orang tua adalah hal mutlak yang mesti dilakukan oleh setiap orang tua, sebagai wujud dari orang beragama. Tapi dalam pelaksanaannya, selain mengukuti ibadah-ibadah rutin yang terjadwal, tapi juga tiap-tiap keluarga punya cara dan rencana. Tentunya dalam mengatur ibadah di rumah orang tua perlu merencanakan dan membicarakannya dengan semua anggota keluarga, untuk melakukan doa-doa khusus di rumah perlu keterlibatan semua anggota keluarga termasuk anak remaja. Hal ini juga dilakukan oleh keluarga Pendeta, PNS, dan Buruh. Hasil wawncara ketiga keluarga ini, Keluarga Pendeta menjawab bahwa pagi sebelum beraktivitas dan malam sebelum tidur mereka selalu berdoa. Selanjutnya, doa bersama anak-anak; Keluarga Pendeta dan Buruh menjawab selalu dilakukan tapi tidak rutin.

Keluarga PNS menjawab selalu dilakukan rutin bersama-sama dengan anak pada malam sebelum tidur. Selanjutnya untuk mengikuti ibadah di gereja pada setiap hari minggu ketiga Keluarga menjawab ya selalu ikut ibadah minggu begitupun ibadah-ibadah lain. Alasan lain yang disampaikan dari Keluarga Buruh adalah dia tidak akan ikut ibadah jika dalam keadaan sakit. Keluarga Pendeta memberi alasan bahwa kami suami-istri pendeta dan semua ibadah selalu hadir untuk bertugas kalau tidak bertugaspun akan hadir juga.

Pada prinsipnya, pertumbuhan rohani tidak terpisah dari pendidikan keagamaan. Artinya kerohanian remaja bertumbuh dari pendidikan dan pengalaman keagamaan yang diajarkan kepada remaja sejak masa kanak-kank. Untuk maksud di atas mengenai ketaatan orang tua dalam beribadah, jawaban ketiga responden menyatakan bahwa doa pribadi setiap pagi dan malam sebelum tidur orang tua selalu melakukannya secara pribadi, sedangkan doa bersama anakanak hanya keluarga PNS yang melakukannya secara ritun, sedangkan keluarga Pendeta dan Buruh menyatakan bahwa mereka juga melakukan doa bersama tapi tidak rutin. Selain doa bersama di rumah, keluarga responden juga menyatakan bahwa mereka juga selalu rutin hadir dalam ibadah-ibadah lain seperti gereja pada hari minggu dan juga persekutuan-persekutuan lain.

Hal itu menunjukan bahwa tanggung jawab orang tua untuk membesarkan mereka bukan hanya memperhatikan hal-hal jasmani, tetapi juga pertumbuhan rohani anak tidak boleh diabaikan. Artinya pendidikan dari orang tua tentang kehidupan rohani bagi anak termasuk remaja adalah hal mutlak dalam keluarga sebab anak juga adalah ciptaan Allah yang membutuhkan pengenalan akan Allah. Melalui pendidikan atau bahkan disiplin keagamaan yang diterapkan dalam 
keluarga termasuk anak-anak seperti; sembayang, membaca kitab suci, dan lain sebagainya, hal ini berpengaruh pada proses perkembangan dan pandangan anak terhadap agama dalam masa remajanya.

Proses keteladanan ini memiliki nilai disiplin yang penting dalam pendidikan agama melalui keteladanan orang tua, karena memperkenalkan perilaku yang baik melalui keteladanan, sama halnya memahami sistem nilai dalam bentuk nyata (Ma'arif, 1991). Disiplin adalah internalisasi nilai dengan cara memberi contohcontoh kongkrit pada remaja. Dalam pendidikan pemberian contoh-contoh ini sangat ditekankan karena tingkah laku orang tua mendapatkan pengamatan khusus dari para anak dan remaja. Dengan demikian, ketaatan beribadah dari ketiga keluarga (orang tua) mereka selalu taat melaksanakan ibadah pada setiap hari minggu maupun ibdah-ibadah lain. Doa pribadipun mereka secara rutin melakukannya setiap hari baik pagi maupun pada malam hari.

\section{Tepat Waktu}

Ketepatan waktu dalam beraktivitas sangat penting, sebab dalam hal mengelola waktu tidak semua orang/anggota keluarga mampu mengatur waktu dengan baik. Orang tua tentunya harus memperhatikan masalah waktu agar apa yang dikerjakan bisa selesai tepat waktu. Terkait ketepatan waktu dalam melakukan berbagai aktivitas di dalam rumah, Keluarga Pendeta: memberi jawaban bahwa untuk kerja-kerja umum dan bebas kadang waktu tidak sesuai atau tidak tapat waktu, tapi yang mengangkut kerja pokok sebagai pendeta tepat waktu. Keluarga PNS: menjawab bahwa ya tepat waktu, tapi terkadang juga terlambat/ tidak tepat waktu karena alasan tertentu. Keluarga Buruh: menjawab bahwa dalam bekerja, saya berusaha tepat waktu baik di rumah maupun di luar rumah, dengan alasan bahwa saya sudah 30 tahun bekerja sebagai buruh pelabuhan dan saya dituntut untuk disiplin dalam bekerja sehingga sudah terbiasa.

Selain ketaatan dalam beribadah, orang tua juga perlu disiplin dan tepat waktu dalam mengelesaikan tugas dan tanggung jawab sebagai orang tua. Dalam hal disiplin orang tua, remaja akan terus belajar untuk selalu memanfaatkan waktu secara efektif (Chandra, 2018). Hal disiplin waktu, ketiga orang tua responden menjawab bahwa selalu berusaha untuk disiplin walaupun terkadang mengalami hambatan-hambatan lain sehingga waktu yang sudah diatur tidak berjalan secara maksimal. Jika hal ini terjadi maka aktivitas yang sudah terjadwal akan menjadi terhambat. Ketiga jawaban di atas, didukung oleh isteri dan remaja berdasarkan hasil wawancara dari masing-masing keluarga (Catatan Lapangan Peneliti).

Hal ini terlihat jelas seperti jawaban responden mengenai indikator tepat waktu di mana ketiga responden menjawab bahwa mereka selalu berusaha untuk tepat waktu, namun terkadang mereka tidak tepat waktu karena kondisi atau hambatan yang memang tidak dapat dihindari. Untuk hal ini, tujuan kedisiplinan adalah perkembangan dari pengembangan diri sendiri dan pengarahan diri sendiri tanpa pengaruh atau kendali dari luar (Rahman, 2008). Kedisiplinan adalah suatu latihan batin yang tercermin dalam tingkah laku yang bertujuan agar orang selalu patuh pada peraturan (Aulina, 2013).

Dengan demikian, untuk indikator tepat waktu ketiga keluarga menjawab bahwa mereka selalu berusaha untuk tepat waktu, namun terkadang mereka tidak tepat waktu karena kondisi atau hambatan yang memang tidak dapat dihindari. 


\section{Mengawasi Remaja di Rumah dan Luar Rumah}

Aktivitas remaja di dalam rumah dan di luar rumah, perlu menjadi perhatian bagi setiap orang tua (Hidayat, 2017), dikarenakan remaja biasa cukup sulit untuk diawasi (Saputra, 2018). Sebab remaja sendiri adalah masa peralihan dari anak ke masa remaja (Fatmawaty, 201). Masa remaja adalah masa di mana mereka dengan bebas melakukan berbagai aktivitas baik di dalam rumah maupun di luar rumah. Aktivitas yang dilakukan oleh remaja jika tidak di awasi dengan baik oleh orang tua, maka remaja akan bebas melakukan segala bentuk kegiatan baik itu yang sifatnya positif tapi juga negatif. Dengan demikian, orang tua dituntut untuk selalu memberi pengawasan terhadap remaja (Hardiyanto \& Romadhona, 2018).

Mengenai pengawasan anak di rumah dan luar rumah, ketiga keluarga cukup memberi perhatian terhadap anak-anak mereka, hal ini dibuktikan dengan hasil wawancara dari ketiga keluarga yaitu: Keluarga Pendeta: menjawab bahwa anak selalu diawasi di rumah, untuk aktivitas anak di luar rumah tidak dilarang tapi selalu diawasi dengan cara di ingatkan dengan pesan-pesan yang harus mereka ketahui; dan jika anak belum masuk rumah kami orang tua akan mencarinya. Keluarga PNS: menjawab bahwa ya di rumah aktivitas anak selalu diawasi; aktivitas anak di luar rumah juga selalu diawasi; dan jika anak belum masuk rumah akan dicari. Keluarga Buruh: menjawab bahwa aktivitas anak di rumah diawasi dan di luar rumahpun saya awasi mereka; dan jika belum masuk rumah mengecek keadaan anak.

Selain itu, menjaga dan mengawasi anak juga penting dilakukan oleh orang tua (Rakhmawati, 2015), sebab aktivitas remaja sendiri ketika tidak dikontrol maka ada kemungkinan untuk terpengaruh dengan melakukan hal-hal yang tidak dikehendaki orang tua (Sunarti, 2004). Untuk indikator mengawasi remaja di rumah dan di luar rumah jawaban ketiga responden tidak ada perbedaan mereka menjawab bahwa untuk setiap aktivitas remaja di rumah dan luar rumah selalu diawasi dan dingatkan bahkan menegur jika terdapat kesalahan.

Sikap demikian perlu diterapkan sebab orang tua adalah pusat kehidupan jasmani dan rohani bagi remaja. Menurut Leving (dalam Ihromi, 2004) mengatakan bahwa pengawasan orang tua adalah suatu keberhasilan anaknya antara lain ditujukan dalam bentuk perhatian terhadap kegiatan remaja baik di rumah maupu di luar rumah, pengawasan penting sebab menekankan arti pencapaian terhadap sesuatu yang diharapkan dari anak, disamping itu orang tua perlu menghadirkan pribadi sukses yang dapat dijadikan teladan bagi anak.

\section{KESIMPULAN}

Hasil analisis jawaban ketiga keluarga yaitu Keluarga Pendeta, PNS dan Buruh dengan merujuk pada sejumlah teori untuk menjawab internalisasi nilai disiplin melalui perencaan orang tua dalam membentuk karakter baik remaja, maka penulis berkesimpulan bahwa mendidik anak membutuhkan pengetahuan yang baik dari orang tua agar dapat mengarahkan remaja menuju proses pendewasaan diri yang tidak salah arah. Perkembangan seorang anak dalam setiap keluarga akan berbeda satu dan yang lainnya. Hal ini disebabkan oleh pola asuh yang berbeda dalam setiap keluarga karena memiliki latar belakang yang berbeda-beda. Anak yang berasal dari latar belakang keluarga yang sibuk, pendidikan orang tua yang minim atau pengetahuan dan pemahaman orang tua yang minim akan sangat 
mempengaruhi perkembangan anak dikemudian hari. Hal tersebut merupakan suatu keterbatasan yang ada pada orang tua selaku ayah dan ibu.

Karena itu, perlu dipahami oleh setiap orang tua bahwa dalam mewujudkan generasi penerus yang baik dibutuhkan pola didik yang baik dan benar sedini mungkin. Orang tua harus menyadari mengenai tanggung jawab yang ada pada dirinya dan mau membuka diri unruk belajar menjadi orang tua yang memiliki pengetahuan yang baik dalam mendidik anak-anaknya dan tentunya semua dilakukan atas dasar cinta demi perkembangan masa depan anak-anak.

Berdasarkan hasil analisis jawaban dari ketiga keluarga di atas, Penulis berkesimpulan bahwa ketiga kelaurga di atas telah melakukan perannya secara baik, meskipun ketiga keluarga mengalami kendala terkait dalam mengatur jadwal aktivitas, ketaatan beribadah, tepat waktu, dan mengawasi remaja di rumah dan luar rumah. Untuk itu, ketiga keluarga perlu memberi perhatian khusus dengan cara merencanakan kembali pola pendampingan dalam membetuk karakter baik remaja. Dengan demikian internalisasi nilai disiplin melalui perencanaan orang tua akan terwujud sesuai dengan harapan keluarga, khusunya remaja akan terbentuk menjadi anak-anak yang berkarakter baik dan mampu mengesuaikan diri dengan perkembangan zaman.

\section{REFERENSI}

Asroha, H. (2010). Perencanaan Pembelajaran. Surabaya: Kopertais IV-Pemprof Jatim.

Aulina, C. N. (2013). Penanaman disiplin pada anak usia dini. Pedagogia: Jurnal Pendidikan, 2(1), 36-49.

Chandra, A. (2018). Hubungan perhatian orang tua dan iklim sekolah dengan disiplin pada siswa SMP N 2 Padang Tualang Kabupaten Langkat. Jurnal Psychomutiara, 1(1), 1-14.

Daradjat, Z. (2003). Peranan Agama dalam Kesehatan Mental. Jakarta: Penerbit Gunung Agung.

Fatmawaty, R. (2017). Memahami Psikologi Remaja. Jurnal Reforma, 6(2), 5565.

Gunarsa, Y. S. D., \& Gunarsa, S. D. (1988). Psikologi Remaja. Jakarta: BPK Gunung Mulia.

Hardiyanto, S., \& Romadhona, E. S. (2018). Remaja dan Perilaku Menyimpang. Jurnal Interaksi: Jurnal Ilmu Komunikasi, 2(1), 23-32.

Hidayat, D. K. (2017). Peran Orang Tua Pengrajin Mebel Dalam Mengembangkan Karakter Kemandirian Remaja Di Desa Langon Kecamatan Tahunan Kabupaten Jepara. Unnes Civic Education Journal, 3(1), 79-88.

Ihromi, T. O. (2004). Bunga Rampai Sosiologi Keluarga. Jakarta: Yayasan Obor Indonesia

Jailani, M. S. (2014). Teori Pendidikan Keluarga dan Tanggung Jawab Orang Tua dalam Pendidikan Anak Usia Dini. Nadwa, 8(2), 245-260.

Ma'arif, S. (1991). Pemikiran Tentang Pembaharuan Islam di Indonesia. Yogyakarta: Tiara Wacana.

Muhtar, T., Suherman, A., Aeni, A. N., \& Jayadinata, A. K. (2018). Internalisasi Nilai Kesalehan Sosial. Sumedang: UPI Sumedang Press. 
Nadlir, M. (2013). Perencanaan pembelajaran berbasis karakter. Jurnal Pendidikan Agama Islam (Journal of Islamic Education Studies), 1(2), 338352.

Nurizka, R., \& Rahim, A. (2020). Internalisasi Nilai-Nilai Pancasila Dalam Membentuk Karakter Siswa Melalui Budaya Sekolah. Elementary School: Jurnal Pendidikan dan Pembelajaran ke-SD-an, 7(1), 38-49.

Prijodarminto, S. (1994). Disiplin Kiat Menuju Sukses. Jakarta: PT Abadi.

Rahman, I. A. (2008). Hubungan antara persepsi terhadap pola asuh demokratis ayah dan ibu dengan perilaku disiplin remaja. Lentera Pendidikan: Jurnal Ilmu Tarbiyah dan Keguruan, 11(1), 69-82.

Rakhmawati, I. (2015). Peran keluarga dalam pengasuhan anak. Jurnal Bimbingan Konseling Islam, 6(1), 1-18.

Saputra, D. (2018). Potret Sosial Remaja Masa Kini (Studi Pada Remaja Pengguna Smartphone Di Kelurahan Kambu Kecamatan Kambu Kota Kendari). Jurnal Neo Societal, 3(3), 547-554.

Sunarti, E. (2004). Mengasuh dengan hati. Jakarta: Elex Media Komputindo.

Suryani, I. (2015). Penanaman nilai-nilai anti korupsi di lembaga pendidikan perguruan tinggi sebagai upaya preventif pencegahan korupsi. dalam Jurnal Visi Komunikasi, 14(02), 285-301.

Uno, H. B. (2008). Perencanaan Pembelajaran. Jakarta: Bumi Aksara.

Yusuf, S. (2004). Psikologi Perkembangan Anak dan Remaja. Bandung: Remaja Rosda Karya. 